\title{
THE UNDERWORLD AND THE DEAD IN THE OLD TESTAMENT1
}

\section{Philip Johnston}

The ancient Israelites, like almost every other people, believed in some form of afterlife. But the precise nature of their belief, the extent to which it affected their life and faith, and its development through time, remain subjects of scholarly discussion. This study focuses on certain key aspects, notably the abode of the dead, the dead themselves, and the significance of both for the living, as portrayed in the Hebrew Bible and indicated by archaeology.

Several widely accepted or increasingly influential views on the underworld and the dead are re-examined and modified or challenged. (i) Most scholars agree that the Old Testament portrays the underworld as the fate of all regardless of their moral or religious standing in life, in contrast with later Jewish and Christian views of differentiated post-mortem fate (ch. 1). (ii) Dahood, Tromp and others argue that there are many more Hebrew references to the underworld and that it therefore held a larger place in Israelite thought than had previously been acknowledged (chs. 2, 3). (iii) Pedersen, Barth and others argue that the underworld was envisaged as a great power overshadowing and invading life, and that many psalmists actually experienced being in the underworld (ch. 4). (iv) Much recent scholarship interprets archaeological and textual evidence to indicate a widespread recognition of and provision for the dead in pre-exilic Israel (chs. 5, 6), emanating in necromancy (ch. 7) and the cult of the dead (ch. 8).

1P.S. Johnston, The Underworld and the Dead in the Old Testament (Unpublished Ph.D. Thesis, University of Cambridge, 1993); supervisor: Dr. R.P. Gordon. 


\section{The underworld}

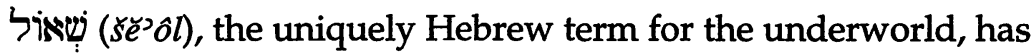
a distinctive pattern of occurrence which is rarely noticed. Only occasionally is it used in general reference, description or personification, while in nearly two-thirds of the relevant texts (41/66 times), it indicates human fate, that to which the ungodly are consigned ( 25 times) and which the godly wish to avoid (7 times). Seldom do the righteous envisage descent there, and only in circumstances which arguably were interpreted as divine judgment (7 times). Twice שוא is given as the destiny of all, but both texts are qualified, Psalm $89: 48 \mathrm{f}$. by the context of judgment and reference to life's brevity and evil

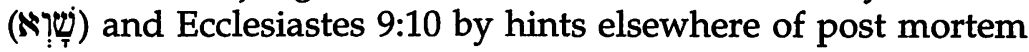
judgment. Other less frequent underworld terms (רשֶׁ,

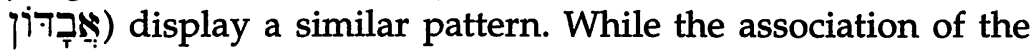
underworld with the wicked may not be absolute and lacks theological reflection, it foreshadows later theological development more than is generally acknowledged.

For many scholars, following Gunkel, rר̣ ('ereș) means not only 'earth' but also 'underworld', as in Akkadian and Ugaritic cognates. This is proposed in over 50 texts and is now accepted in a modern version (NRSV, Jer. 17:13). However, in many of these texts $ץ$ more likely means 'world', 'earth' or 'ground'. In some a compound phrase,

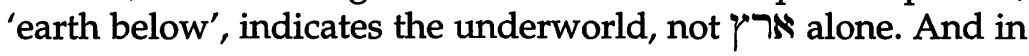
a few, אר could mean 'underworld', but this is required in none, not even Isaiah 26:19 (examined in detail), and it could equally mean 'ground'. Thus the semantic range of probably does not include the underworld. This accords with the Old Testament's distinction between this life, lived before Yahweh, and the underworld, separated from him.

Water has associations with the underworld since it is a force of chaos and destruction and is also located in the earth's depths. However, several attempts to strengthen the association are unsuccessful. Various terms for water and mire

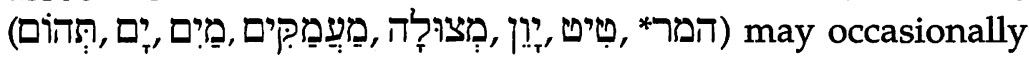
have underworld connotations (Dahood, Tromp), but are hardly names for it. The identification of an underworld river 


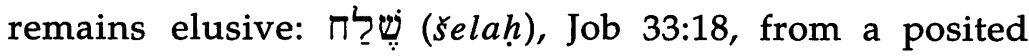
Canaanite deity (Tsevat), remains possible but unproven, $\left({ }^{\prime} \bar{e} d\right)$ is unlikely, and other suggestions implausible. The suggestion of a cosmic river ordeal after death reflected in certain psalms (McCarter) is conceptually inappropriate and misinterprets both Akkadian and Hebrew texts. Thus, water is associated but not confused with the underworld.

Some scholars interpret the Hebrew underworld more as a power invading life than as a destiny after death. The Israelites, conceiving only of totalities, thought of illness or misfortune as being 'in Sheol' (Pedersen), or as a 'real but partial' experience of it (Christophe Barth). This view has been widely accepted (e.g. Johnson, Maag, Tromp, Kraus). However, it is based on questionable anthropology, insists on literal rather than metaphorical interpretation of poetic texts without justification, over-simplifies the pattern of underworld reference in the psalms, and never resolves the ambiguity of being both 'near' and 'in' Sheol, or of a 'real but partial' experience of it. Even in their darkest distress, psalmists are still able to pray to and hope in Yahweh, so are not in the underworld.

\section{The dead}

Iron Age burials in Palestine reveal clear differences between lowland Canaanite graves and highland Judahite tombs, with their various assemblages of artifacts. But the proposals of deferential treatment of human bones (Meyers) and of continued sustenance of the deceased (Bloch-Smith) lack archaeological evidence. In the Old Testament the burial of most but not all major figures is noted, with specific formulae used for patriarchs ('gathered to his people') and for kings who died naturally ('slept with his fathers'). However, there is little record of funerary practice, and burial location is never linked to consultation or veneration of the dead, except possibly in Ezekiel 43:7ff. Thus neither archaeological nor textual evidence concerning burial suggests continuing interaction with the dead.

The Hebrew Bible rarely refers to the dead, and

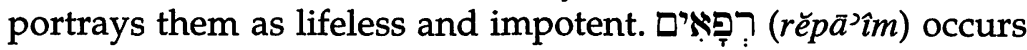
only 8 times in this sense. The רפאים are cut off from Yahweh, a 
flaccid assembly which must be roused to greet a newcomer. Never are they linked with a founder/patron, named individually, invoked as protectors, invited to feasts or consulted in necromancy, in marked contrast to the Ugaritic rpum (as often interpreted). Similarly, אלדיהים ('élôhîm) occurs only twice of the dead, both times in non-Yahwistic usage, and one of these in a possible necromantic formula (1 Sam. 28:13). Other proposed references are unclear or unlikely. Thus the Hebrew writers are largely unconcerned with the dead.

Consultation of the dead is mentioned more often, though still infrequently: several prohibitions, one account, and a few other references. The debated term בis ('ôb) probably means 'spirit/medium', not 'pit' (Hoffner) or 'instrument' (Ebach and Rüterswörden) and its association with Tropper) remains dubious. The illegality of necromancy is integral to the account of Saul's visit to Endor, and therefore hardly a later addition to an ancient text from a more austere period. The text gives little indication of necromantic ritual. Attempts to trace necromancy in Isaiah 28 (van der Toorn) and elsewhere remain inconclusive. Necromancy certainly existed, but was deemed illicit from an early period, and did not preoccupy the biblical authors or redactors.

The existence of a widespread cult of the dead in preexilic Yahwism, whose traces have been obscured but not eradicated by Deuteronomistic editing, is increasingly proposed by scholars (e.g. Lewis). However, the only clear Hebrew references are to the Moabite cult associated with Baal Peor. The passing, almost casual mention of food offered 'to/for a dead person' (Dt. 26:14) suggests that prohibiting a widespread Israelite communion with the dead is not a major concern of Deuteronomy. מַרֵ (marzēah), like its West Semitic cognates, indicates a feast which is sometimes funerary (so probably Jer. 16:5), but often not (so Am. 6:7). Suggestions that

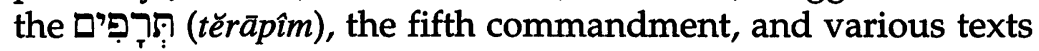
(e.g. 1 Sam 28, Is. 28, Ps. 16:3) imply veneration of the ancestors remain unconvincing, though a few texts (e.g. Is. 57, Ezk. 43:7) may allude to it. Thus the evidence for a widespread pre-exilic cult of the dead remains meagre at best. 
To conclude, the Israelites did not ignore death, burial, the dead, or the underworld, but neither were they preoccupied with them to the extent many scholars suggest. After all, their Yahweh was the god of the living, not the dead. 